Durk Zandstra

Francisco Abecasis

Nia Taylor

Vladimir Damjanovic

Luciano Silvestri

H. K. F. van Saene

\section{For control of colonisation with extended-spectrum $\beta$-lactamase-producing bacteria, SDD does work}

Accepted: 9 October 2012

Published online: 4 January 2013

(C) Springer-Verlag Berlin Heidelberg and ESICM 2012

An author's reply to this comment is available at:

doi:10.1007/s00134-012-2781-z.

\section{Dear Editor,}

We read with interest the French report entitled "Clinical impact and risk factors for colonization with extended-spectrum $\beta$-lactamase-producing bacteria in the intensive care unit" [1] as we are aware that these researchers have previously reported on this topic. Brun-Buisson et al. [2] have an understanding of endemicity and outbreaks of carriage and infection due to extended-spectrum betalactamase-producing Enterobacteriaceae (ESBL-PE). In 1989, they described an outbreak of carriage and infection due to ESBL-producing Klebsiella pneumoniae. Carriage and infection rates were 20 and $10 \%$, respectively. Reinforcement of hygiene practices failed to control the outbreak until they introduced a form of selective decontamination of the digestive tract (SDD) using enteral antimicrobials aimed at the eradication of carriage of the outbreak strain The enteral antimicrobial cocktail applied included polymyxin E, neomycin and nalidixic acid. The carriage and infection rates dropped to 3 and $0 \%$, respectively. In a later study by other authors enteral antimicrobials were shown to significantly reduce absolute carriage, a more appropriate term for colonisation pressure [3]. Colonisation pressure is qualitatively defined as the proportion of patients who carry the outbreak strain (percentage) in the ICU, whilst absolute carriage also takes into account the level of carriage of the outbreak strain in the ICU (qualitatively and quantitatively).

It is puzzling to us why 23 years later, Brun-Buisson et al. overlooked the one intervention that does work for the control of endemicity and outbreaks of ESBL-PE [4] when writing in their recent report that 'our data suggest that additional measures may be warranted to control the spread of the latter species' [1].

Abecasis et al. [4] recommend the more up-to-date enteral combination of polymyxin $E$ and tobramycin. This positive experience comes from a paediatric ICU with a different setting, patient population and epidemiology compared with the Parisian ICU. However, we believe that SDD is worth trying as the combination of polymyxin $\mathrm{E}$ and tobramycin covers both community and ICU-associated ESBL-PEs such as E. coli, E. cloacae and K. pneumoniae, the three different strains described by another French group [5].

Finally, improving carbapenem use is a major challenge for Parisian intensivists. In contrast, the 25-year experience with SDD has demonstrated that the addition of enteral antimicrobials (polymyxin/tobramycin) to parenteral antimicrobials such as cefotaxime and carbapenems has prolonged the antibiotic era of these useful systemic agents, as the essential component of SDD (i.e., the enteral antibiotics) controls gut overgrowth of E. coli, E. cloacae and $K$. pneumoniae, the major risk factor for de novo development of resistance.

\section{References}

1. Razazi K, Derde LPG, Verachten M, Legrand P, Lesprit P, Brun-Buisson C (2012) Clinical impact and risk factors for colonization with extended-spectrum $\beta$-lactamase-producing bacteria in the intensive care unit. Intens Care Med. doi: 10.1007/s00134-012-2675-0

2. Brun-Buisson C, Legrand P, Rauss A, Richard C, Montravers F, Besbes M, Meakins JL, Soussy CJ, Lemaire F (1989) Intestinal decontamination for control of nosocomial multi-resistant Gram-negative bacilli. Ann Intern Med 110:873-881

3. Viviani M, van Saene HK, Dezzoni R, Silvestri L, Di Lenarda R, Berlot G, Gullo A (2005) Control of imported and acquired methicillin-resistant

Staphylococcus aureus (mrsa) in mechanically ventilated patients: a doseresponse study of enteral vancomycin to reduce absolute carriage and infection. Anaesth Intensive Care 33:361-372

4. Abecasis F, Sarginson RE, Kerr S, Taylor N, van Saene HKF (2011) Is selective digestive decontamination useful in controlling aerobic Gramnegative bacilli producing extended spectrum beta-lactamases? Microb Drug Resist 17:17-23

5. Oostdijk EAN, de Smet AMG,

Kesecioglu J, Bonten MJM (2012)

Decontamination of cephalosporinresistant Enterobacteriaceae during selective digestive tract decontamination in intensive care units. J Antimicrob Chemother 67:2250-2253

\section{Zandstra}

Department Intensive Care, OLVG, 1st Oosterpark Str 279, 1090 HM Amsterdam, The Netherlands

\section{F. Abecasis}

Pediatric Intensive Care Unit, Department of Pediatrics, Centro Hospitalar Lisboa Norte, Lisbon, Portugal

N. Taylor · V. Damjanovic ·

H. K. F. van Saene (匹)

Institute of Ageing and Chronic Disease, University of Liverpool, Liverpool, UK e-mail: vansaene@liv.ac.uk

N. Taylor e-mail: nia.taylor@liv.ac.uk

\section{Silvestri}

Department of Emergency, Anesthesia and Intensive Care, Presidio Ospedaliero di Gorizia, Via Fatebenefratelli 34, 34170 Gorizia, Italy 